\title{
Prime Ministerial powers of patronage: Ideology and Cabinet selection under Margaret Thatcher 1979-1990
}

\author{
Tom McMeeking ${ }^{1} \cdot$ Tim Heppell $^{1} \cdot$ Andrew Roe-Crines $^{2}$
}

Accepted: 26 January 2021

(c) The Author(s) 2021

\begin{abstract}
This article will examine how Margaret Thatcher utilised the Prime Ministerial power of Cabinet ministerial appointment between 1979 and 1990. The article will utilise the Norton taxonomy on the Parliamentary Conservative Party (PCP) to determine the ideological disposition (non-Thatcherite versus Thatcherite) of her Cabinet members across her eleven years in office. It will assess the ideological trends in terms of appointments, promotions and departures from Cabinet and it will use archival evidence to explore the advice given to Thatcher to assist her decision-making. Through this process the article will demonstrate how Thatcher was more ideologically balanced than academics have traditionally acknowledged when discussing her Cabinet selections. Moreover, the article will also demonstrate the significance attached to media presentation skills to her decision-making, thus challenging the emphasis on ideology as a dominant determinant of Cabinet selection.
\end{abstract}

Keywords Conservative party · Margaret Thatcher · Thatcher government 1979$1990 \cdot$ Ministerial selection $\cdot$ Cabinet ministers

\section{Introduction}

This article contributes to the academic literature on the political leadership of Margaret Thatcher, focusing on the powers of patronage that a Prime Minister possesses in terms of Cabinet selection. The article will address the following three research questions: first, how ideologically balanced were her Cabinets; second, did she demonstrate a bias towards Thatcherites in terms of promotions into Cabinet; and, third, was there a bias towards non-Thatcherites in terms of departures from Cabinet? In

Tim Heppell

t.heppell@leeds.ac.uk

1 School of Politics and International Studies, University of Leeds, Leeds, England

2 Department of Politics, University of Liverpool, Liverpool, England 
answering these questions, the article will use archival evidence to gain insights into the factors shaping her decision-making on Cabinet selection.

These questions demonstrate how patronage can also be seen as a tool of party management-i.e., to what extent should the Prime Minister respond to their factions' expectation that they should be dominant numerically within the ministerial and Cabinet ranks? (King 1994, p. 210). On that conundrum, there is a general consensus within the academic literature on how Thatcher demonstrated a bias in favour of ideologically like-minded Conservatives-Holmes has argued that through Cabinet reshuffles Thatcher 'outmanoeuvred' the non-Thatcherites (Holmes 1989, p. 91); Smith (1994, p. 343) spoke of her 'removing' them; whilst Thomas (1998, p. 37) claimed that the 'changes she made were not primarily on the grounds of competence, but in order to shift the ideological balance' of Cabinet. Yet Thatcher used her memoirs to suggest that ideological balance within Cabinet was important to her (Thatcher 1993, p. 418).

This article attempts to identify the evidence to support the claim that Thatcher sought ideological balance, as against the academic assumptions that she failed to do so. Assuming that ideology mattered is a legitimate claim given the following. First, ideology influenced voting in the Conservative Party leadership election of 1975 through which she won the leadership. Cowley and Bailey (2000) have identified how those identifiable with the right wing were more likely to vote for Thatcher in the leadership ballots, and those identifiable with the one nation left were more likely to vote for Edward Heath in the first ballot and then William Whitelaw in the second ballot. Second, not only did ideology matter within the PCP, but we can assume that when they entered office after victory at the General Election of 1979: those who had been her backers would expect ministerial rewards, but those who had not supported her would still hope for ministerial advancement (Evans 2009, p. 102). Thatcher was thus the 'monopoly supplier' of a good in short supply for which there was an enormous demand (King and Allen 2010, p. 251).

\section{The Norton taxonomy}

The article exploits Norton's taxonomy of the PCP in the late Thatcher era. Norton identified the ideological composition of the PCP (as of 1989), in order to determine whether her leadership had acted as a 'transmission belt' for the creation of a Thatcherite PCP and the erosion of one-nation Conservative sentiment (Norton 1990). Norton constructed a spectrum of Conservative thought and he positioned each Conservative parliamentarian on it. ${ }^{1}$ He determined the position

\footnotetext{
${ }^{1}$ Over time the Norton taxonomy would become a dated representation of the ideological fault-lines within British Conservatism. Its focus on the economic divide (wet-dry) underplayed the importance of the conflicts over European policy and social, sexual and moral issues and how these should be considered separately. This is because, within the post-Thatcherite PCPs, many Conservatives did 'not adhere to a straightforward distinction based on the left of Conservatism being economically wet, Europhile and social liberal, and the right of Conservatism being economically dry, Eurosceptic and socially conservative....[as]... a lot of cross-cutting opinions, or zig-zagging, exist[ed] across these three ideological dividing lines', thus explaining the party management difficulties for leaders after Thatcher (Heppell, 2020: 18).
} 
of each member via the use of division lists, membership of party groupings and public comment, in relation to the dominant ideological divides of Conservatism in the Thatcherite era-i.e., economic policy; European policy and social, sexual and moral issues. The Norton taxonomy subdivided the PCP into the following groupings:

(1) Critics The non-Thatcherite wing comprised a 'wet' grouping (strongly interventionist, pro-European, socially liberal) and the less rebellious and more biddable 'damp' grouping (moderately interventionist, pro-European, socially liberal). In the 1989 PCP Norton identified that the Thatcherite critics comprised 67 Conservative parliamentarians (wets 27 and damps 40).

(2) Loyalists Located within the centre ground were loyalist Conservatives-i.e., those who lacked strong ideological commitments and whose loyalty was to the existing leadership and policy positions. As of 1989 Norton identified this to be the strongest grouping within the PCP, totalling 217 and over half of their parliamentary representation.

(3) Populists Norton identified a distinctive populist grouping $(n=17)$ who were interventionist on economic issues, but Eurosceptic and socially conservative.

(4) Thatcherites Norton identified that as of 1989 a total of 71 PCP members could be defined as Thatcherites. Norton argued that there were three variants of Thatcherite: the neo-liberals who were economically dry; socially liberal and Eurosceptic $(n=15)$; the Thatcher group who hold a dry economic viewpoint and although essentially sceptical vis-à-vis further European integration and moderately socially conservative, their primary loyalty was to the style of leadership that Thatcher embodied $(n=30)$; and the Tory right—economically dry, moderately sceptical on Europe yet their primary ideological focus was on traditional social conservatism $(n=26)$.

What was intriguing about the Norton taxonomy was that the two blocs on the non-Thatcherite left and Thatcherite right were significantly outnumbered by the loyalist centrist group within the PCP-i.e., 18.1 percent were critics of Thatcherism and 19.1 percent were Thatcherites (Norton 1990). This article argues that utilising the Norton taxonomy provides a legitimate basis for examining the ideological composition of the Cabinet across the Thatcher era.

Before proceeding three caveats need to be acknowledged. First, the Norton taxonomy lists the ideological categorisation of Conservative parliamentarians from the 1987-1992 Parliament $(n=356)$ but it does not capture the ideological positions of those who were Cabinet ministers in the period of 1979 to 1987 but no longer members of Parliament after 1987. With this study excluding the small number of Cabinet members who were based within the House of Lords, the number of Cabinet members the Norton study covers is forty-seven. Of those thirteen were not located ideologically within the Norton taxonomy as they had left Parliament at the General Elections of 1983 or 1987 . In these cases, their parliamentary voting behaviour has been profiled, as had their membership of party groups and public comment (as per the methods that Norton used himself) in order to locate them. 
Second, whilst the paper assumes that the ideological composition of the Cabinet will have been $a$ consideration when Thatcher was appointing ministers, it also acknowledges that ministerial preferment will be a by-product of other variables such as competence, age, experience, region, gender, loyalty or constituency marginality. As such, when this paper examines the outputs of Thatcher's Cabinet appointments and dismissals, from the inputs (the reasons why she made these choices) we are not claiming a direct correlation between ideological disposition of ministerial preferment, but highlighting the trends that existed between ideological disposition and her patronage (on these debates, see Heppell 2005, p. 150-1).

Third, in noting that other variables will be an influence on ministerial selection, we acknowledge that Prime Ministers do face constraints, as balances need to be found for reasons of political presentation, party management and succession planning. Moreover, given that ministers are primarily drawn from the House of Commons, we also need to note that this is a small talent pool to select from (King and Allen 2010). One notable restriction will be the obstacles to female representation in Cabinet that this creates, as the male-female balance was respectively 331-8; 384-13 and 359-17 across the three Parliaments of her tenure. Of that restricted talent pool, some will lack the administrative ability, or the intellect, temperament or ambition to hold ministerial office. Establishing who will be suitable for consideration creates a powerbase for the Whips' Office, but their input will have a greater influence on junior ministerial appointments than Cabinet appointments. As junior ministerial posts act as a conveyer belt to the Cabinet then the preferences within the Whips' Office itself can act as an influence on getting onto the ministerial ladder in the first place. Here it is worth noting the influence of long-standing whip, Tristan Garel-Jones, who used his Blue-Chip grouping of elite Tories to advance the ministerial careers of like-minded (economically damp and pro-European) Conservatives, to the lower rungs of the ministerial ladder (Moore 2013, p. 646).

\section{Cabinet ministers 1979-1990: overall ideological profile}

Our first research question asks whether Thatcher secured and maintained ideological balance within her Cabinet? Table 1 provides aprofile covering the ideological composition of the Cabinet covering all twenty-one Cabinets that she constructed. Table 2 then notes the ideological disposition of each individual who was a member of the Cabinet at some time between 1979 and 1990. It is worth noting that some of her Cabinets were long standing - for example, her first Cabinet lasted from May 1979 to January 1981- but the cumulative effect on resignations (enforced changes) alongside her deliberately timed reshuffles (selective dismissals) led to considerably more Cabinets in the latter years of her Prime Ministerial tenure. Her first four-year term had five Cabinets; her second four-year term had six Cabinets; and her final and truncated three-year term had ten Cabinets.

Using the Norton taxonomy as a basis for evaluation the findings suggest the following. The ideological balance of the first Cabinet-May 1979 to January 1981-tilted in favour of the non-Thatcherites (eight) as compared to the Thatcherites (six) with the remainder defined as loyalist. This supports the view that some 
Table 1 The Ideological Composition of the Thatcher Cabinets 1979-1990

\begin{tabular}{llll}
\hline Groups & Non- & Loyalist & Thatcherites \\
Cabinets $(n=)$ & Thatcher- & & \\
& ites & \\
\hline
\end{tabular}

\begin{tabular}{|c|c|c|}
\hline \multicolumn{3}{|l|}{ First Term 1979-83 } \\
\hline May 1979-Jan 1981 (19) & 8 & 5 \\
\hline Jan 1981-Sept 1981 (19) & 7 & 6 \\
\hline Sept 1981-Apr 1982 (20) & 5 & 7 \\
\hline Apr 1982-Jan 1983 (19) & 5 & 6 \\
\hline Jan 1983-June 1983 (19) & 5 & 7 \\
\hline \multicolumn{3}{|l|}{ Second Term 1983-87 } \\
\hline June 1983-Oct 1983 (18) & 3 & 8 \\
\hline Oct 1983-Sept 1984 (18) & 3 & 8 \\
\hline Sept 1984-Sept 1985 (18) & 3 & 8 \\
\hline Sept 1985-Jan 1986 (19) & 5 & 7 \\
\hline Jan 1986-Mar 1986 (19) & 4 & 9 \\
\hline Mar 1986-June 1987 (19) & 4 & 9 \\
\hline \multicolumn{3}{|l|}{ Third Term 1987-90 } \\
\hline June 1987-Oct 1987 (18) & 4 & 9 \\
\hline Oct 1987-Jan 1988 (18) & 4 & 9 \\
\hline Jan 1988-July 1988 (18) & 4 & 9 \\
\hline July 1988-July 1989 (19) & 4 & 10 \\
\hline July 1989-Oct 1989 (20) & 5 & 10 \\
\hline Oct 1989-Jan 1990 (20) & 5 & 11 \\
\hline Jan 1990-Mar 1990 (20) & 5 & 11 \\
\hline Mar 1990-July 1990 (20) & 5 & 11 \\
\hline July 1990-Nov 1990 (20) & 5 & 11 \\
\hline Nov 1990-(20) & 6 & 11 \\
\hline
\end{tabular}

No member of the Norton 'populists' grouping was appointed to Cabinet

$n=$ Based on members of PCP in Cabinet and excludes members of the House of Lords

Conservative had: e.g., Prior recalled that the balance looked 'better for our wing of the party than I had dreamt possible', with the 'dissidents', including himself, outnumbering her 'main supporters'-Howe plus Keith Joseph, John Nott and John Biffen, whom Prior thought were 'not a very impressive bunch' (Prior 1986, p. 1).

That balance was adjusted most notably via the reshuffle in September 1981given the removals of Ian Gilmour and Mark Carlisle (non-Thatcherites) and the appointments of Lawson and Norman Tebbit (Thatcherites). This was clearly the intention of Thatcher herself-she wanted more of her economic supporters into Cabinet as 'there were too many' who 'did not share' her view (Thatcher 1993, p. 149). That a shift had occurred was acknowledged by some of the new entrants of 1981. Lawson recalled that Thatcher had now 'secured a Cabinet with a Thatcherite majority' (Lawson 1992, p. 123); Norman Fowler described it was the most 
'extensive' of her reshuffles (Fowler 1991, p. 155); whilst Norman Tebbit, described it as a 'turning point' as the 'balance in the Cabinet was decisively changed' (Tebbit 1989, p. 181).

That ideological balance was a consideration within the calculations of Cabinet formation is evident from the advice that Thatcher received from her confidants. For example, in August 1982, her Parliamentary Private Secretary, Ian Gow, offered the following insights on the ideological composition of the Cabinet: 'putting it at its worst, we now have a majority in the Cabinet' and as 'the balance now is better than at any time during your administration' even if 'this is not as strong a majority as we would like' (Thatcher, MSS, Churchill Archive Centre CAC, 'Shuffle: thoughts on MT's strength in Cabinet', THCR 2/7/3/1 f29, 25 August 1982). However, the 1981 reshuffles did not constitute the start of a trend for reducing the non-Thatcherite membership of the Cabinet. Thereafter, in the first parliament of 1979 to 1983 , the only ideologically significant adjustment was the replacement of the Thatcherite, Nott, (in January 1983) with the ideologically centrist and loyalist, Tom King.

If the sum total was that the Cabinet was more Thatcherite and less non-Thatcherite at the end of the first term than it was at the beginning of their time in office, then what patterns can be identified in her second term? Thatcher used her post-General Election reshuffle to further reduce non-Thatcherite membership of her Cabinet as she dismissed the non-Thatcherite, Pym, as Foreign Secretary. However, she did not use this as an opportunity to advance younger Thatcherites into the Cabinet- the Thatcherites entered the second Thatcher term with seven members (the same as before the reshuffle) and they would end the 1983 to 1987 Parliament numbering just six, which was the same number of Thatcherites when Thatcher first entered Downing Street back in 1979. No further erosion of non-Thatcherite sentiment within the Cabinet was evident by 1987 as table one demonstrates. It is worth noting how the September 1985 reshuffle, which led to the elevations to Cabinet of the Kenneth'sBaker and Clarke-and to be discussed in more detail later on-involved Thatcher being explicitly advised of the following:

You need two or three high-profile wets to come into the Cabinet. Policies will hardly be affected in the next two years, but perceptions will be.... Prospective cabinet members should have one particular qualification: they must not be 'one of us' (Thatcher, MSS, CAC, 'Wolfson notes: Ministerial Changes', THCR 1/14/14 f129, 22 August 1985).

What of her final term of office between 1987 and 1990? What is most revealing from using the Norton taxonomy in relation to Cabinet appointments is the discovery that her final Cabinet was not that dissimilar to her first Cabinet in terms of ideological balance-i.e., just as she entered office with a Cabinet in which the non-Thatcherites were double in number than the Thatcherites (by eight to four) the same was true in November 1990, as she had six non-Thatcherites as compared to three Thatcherites. This finding should be viewed as being problematic for political historians in terms of replicating the assumption that Thatcher simply removed the wets-her critics - from within her Cabinet-as per those comments identified in our introduction. By her new appointments in her final term-twelve in total- three were critics (Chris Patten, David Hunt and William Waldegrave); seven 
were centrists and only two were Thatcherites (Norman Lamont and Peter Lilley). Thatcher had contributed to the construction of an essentially non-Thatcherite Cabinet at time of the Conservative Party leadership election of November 1990.

This had consequences as the Cabinet were central to her removal from the party leadership, after she had defeated the challenger, Heseltine, by 204 votes to 152 in the first parliamentary ballot. Although victorious she was short (by four votes) of the additional fifteen percent lead rule that existed in the Conservative Party leadership election rules at that time, thus forcing her to proceed to a second ballot (Heppell 2008, pp. 80-83). To hold onto her existing levels of support, she needed, at a minimum, to maintain the backing of her own Cabinet, whereupon Thatcher realised that they were beginning to withhold their support. With some Cabinet members now prepared to resign unless she withdrew, she realised that even if she did defeat Heseltine in the second ballot, she would 'lack the authority to govern' (Thatcher 1993, pp. 851-853) whereupon she resigned.

\section{Ideological disposition and cabinet appointments}

Our second research question considers new appointments into Cabinet and asks whether Thatcher displayed a bias in favour of appointing Thatcherites. After the formation of her first Cabinet in May 1979, Thatcher conducted four reshuffles in her first term, drafting in a total of six new members of Cabinet. The new appointments in the respective reshuffles of 1981 showed her desire to advance more of her ideological sympathisers. Although Fowler (January) and Parkinson (September) were identifiable as loyalists, the other new entrants-Brittan (January) and then Tebbit and Lawson (September) were clearly ideological sympathisers (Norton 1990). Only one new entrant to Cabinet was appointed before the landslide General Election of 1983 was secured, that being the ideologically centrist, King, as mentioned above.

In her second term, she drafted in a total of ten new Cabinet ministers across five reshuffles. During this period, Thatcher was more balanced in the ideological makeup of her new appointments. The post-general election reshuffle (June 1983) saw Thatcher introduce into the Cabinet two figures who ideologically centrist-Jopling and Peter Rees, and later in the year she promoted to Cabinet the ideological sympathising, Nicholas Ridley (September 1983). Of the seven additional new appointees to Cabinet in the remainder of the second Thatcher term, it is worth noting that alongside another three ideological centrists-John McGregor; Paul Channon and Malcolm Rifkind-Thatcher appointed three non-Thatcherites in the shape of Douglas Hurd, plus Clarke and Baker. The only advancement secured by the Thatcherite wing thereafter in the 1983-1987 Parliament was the appointment of John Moore in 1986 (Campbell 2003, p. 225).

Thatcher was an admirer of Baker, despite his Heathite credentials, because he was a 'superb communicator' (Thatcher 1993, p. 420) and in her memoirs she would note that for 'every few Josephs and Ridleys you needed at least one Ken Baker to concentrate on communicating the message' (Thatcher 1993, p. 758). The focus on presentation was central to the advice that Thatcher received in preparation for the September 1985 reshuffle. On potential 'new faces' Thatcher was informed by her 
Table 2 The Ideological Disposition of Individual Cabinet Members 1979-1990

\begin{tabular}{|c|c|c|c|}
\hline $\begin{array}{l}\text { Groups } \\
\text { Cabinet Members 1979-1990 }\end{array}$ & $\begin{array}{l}\text { Non-Thatcherites } \\
n=14\end{array}$ & $\begin{array}{l}\text { Loyalist } \\
n=20\end{array}$ & $\begin{array}{l}\text { Thatcherites } \\
n=13\end{array}$ \\
\hline Margaret Thatcher 1979-1990 & & & $*$ \\
\hline Geoffrey Howe 1979-1990 & & & $*$ \\
\hline John Biffen 1979-1987 & & & $*$ \\
\hline William Whitelaw 1979-1988 & $*$ & & \\
\hline Norman St John Stevas 1979-1981 & $*$ & & \\
\hline Ian Gilmour 1979-1981 & $*$ & & \\
\hline Peter Walker 1979-1990 & $*$ & & \\
\hline Francis Pym 1979-1983 & $*$ & & \\
\hline Mark Carlisle 1979-1981 & $*$ & & \\
\hline James Prior 1979-1984 & $*$ & & \\
\hline David Howell 1979-1983 & & $*$ & \\
\hline Michael Heseltine 1979-1986 & $*$ & & \\
\hline Patrick Jenkin 1979-1985 & & $*$ & \\
\hline Keith Joseph 1979-1986 & & & $*$ \\
\hline Humphrey Atkins 1979-1982 & & $*$ & \\
\hline George Younger 1979-1989 & & $*$ & \\
\hline Angus Maude 1979-1981 & & & $*$ \\
\hline John Nott 1979-1983 & & & $*$ \\
\hline Nicholas Edwards 1979-1987 & & $*$ & \\
\hline Leon Brittan 1981-1986 & & & $*$ \\
\hline Norman Fowler 1981-1990 & & $*$ & \\
\hline Norman Tebbit 1981-1987 & & & $*$ \\
\hline Nigel Lawson 1983-1989 & & & $*$ \\
\hline Cecil Parkinson 1981-83; 1987- & & $*$ & \\
\hline Tom King 1983- & & $*$ & \\
\hline Peter Rees 1983-1985 & & * & \\
\hline Michael Jopling 1983-1987 & & * & \\
\hline Nicholas Ridley 1983-1990 & & & $*$ \\
\hline Douglas Hurd 1984- & $*$ & & \\
\hline John McGregor 1985- & & * & \\
\hline Kenneth Clarke 1985- & $*$ & & \\
\hline Kenneth Baker 1985- & $*$ & & \\
\hline Paul Channon 1986-1989 & & $*$ & \\
\hline Malcolm Rifkind 1986- & & * & \\
\hline John Moore 1986-1989 & & & $*$ \\
\hline John Major 1987- & & $*$ & \\
\hline John Wakeham 1987- & & $*$ & \\
\hline Tony Newton 1988- & & $*$ & \\
\hline Norman Lamont 1989- & & & $*$ \\
\hline Peter Brooke 1989- & & $*$ & \\
\hline David Waddington 1989- & & $*$ & \\
\hline John Gummer 1989- & & $*$ & \\
\hline
\end{tabular}


Table 2 (continued)

\begin{tabular}{llll}
\hline $\begin{array}{l}\text { Groups } \\
\text { Cabinet Members 1979-1990 }\end{array}$ & $\begin{array}{l}\text { Non-Thatcherites } \\
n=14\end{array}$ & $\begin{array}{l}\text { Loyalist } \\
n=20\end{array}$ & $\begin{array}{l}\text { Thatcherites } \\
n=13\end{array}$ \\
\hline $\begin{array}{l}\text { Chris Patten 1989- } \\
\text { Michael Howard 1990- }\end{array}$ & $*$ & $*$ & \\
Peter Lilley 1990- & & \\
David Hunt 1990- & $*$ & \\
William Waldegrave 1990- & $*$ & \\
\hline
\end{tabular}

advisors that they 'must be good communicators' and those identified as the examples, Baker, McGregor and Clarke were all promoted to Cabinet, even though two of them (Baker and Clarke) were non-Thatcherites (Thatcher, MSS, CAC, Sherbourne minutes on reshuffle, THCR, 1/14/14 f136, 22 August 1985). As Party Chair, Tebbit, concurred with much of this advice and recommended Baker and Clarke, both of whom he defined as a 'safe pair of hands', as was Channon, although his advancement was delayed until the 1986 reshuffle (intriguingly Tebbit's suggestion that the Thatcherite, Lamont, should join the Cabinet was ignored) (Thatcher, MSS, CAC, Tebbit letter to Thatcher, THCR, 1/14/14 f 123, 27 August 1985).

Of the others who were identified as 'good communicators' there was Moore and Patten but also Tony Newton-it was a case of promotions delayed, as all three would later join the Cabinet, although Thatcher rejected the advice to switch the Heseltine to the DHSS and Walker to Defence, even though both suggestions were made on the basis of them both being 'good communicators' (Thatcher, MSS, CAC, Sherbourne minutes on reshuffle, THCR, 1/14/14 f136, 22 August 1985). Ultimately, Thatcher followed the advice of Wolfson in two key ways: first, that it would be a 'mistake' to 'sack' Walker, or 'even move him from Energy 'where he is a perceived success'; and second, it would be 'illogical' to move Heseltine on from Defence (had she done so the crisis that was the Westland Affair could have been averted) but if she must the recommendation was Trade and Industry (Thatcher, MSS, CAC, 'Wolfson notes: Ministerial Changes', THCR 1/14/14 f129, 22 August 1985).

The third term Thatcher Cabinet was significantly more volatile than the first and second terms. Twelve new Cabinet appointments were made, which were made across ten reshuffles, including the one that took place in the immediate aftermath of the General Election victory of 1987 (Fowler 1991, pp. 286-288). The majority of the new appointees were ideologically centrists within what Norton defined as the loyalist categorisation. Those included for promotions included Newton and Gummer, as well as John Wakeham, Peter Brooke and David Waddington, but they also included two defined as loyalists that require further consideration. First, Major was appointed as Chief Secretary to the Treasury in June 1987 and although Norton defined him as a loyalist as of 1989, the ideological base of his vote when winning the leadership of the Conservative Party was located on the Thatcherite right of the PCP (Cowley and Garry 1998). Second, although the Norton taxonomy positioned Michael Howard-promoted to the Cabinet in 1990 - as a loyalist, he was to emerge thereafter in the 1990s as being more identifiable with the Thatcherite right (Heppell 2002). If Howard is categorised 
as a loyalist based on his conduct in that era, then that means that Thatcher advanced into Cabinet only two who were ideologically aligned to her in the whole of her final term-Lamont and Lilley. There is a certain irony in the following fact. We know from the literature on the Conservative Party leadership election of 1990 that the non-Thatcherite wets tended to vote for Heseltine and the dries voted for Thatcher (Cowley and Garry 1998) and yet three of the last five new entrants into Cabinet (in 1989 and 1990) were clearly identifiable with the wets-Patten, Hunt and Waldegrave. On the appointment of Waldegrave, Thatcher recalled how her Chief Whip, Tim Renton, lobbied hard for Waldegrave to be appointed, and even though she knew he was not an 'ally' she claimed that 'I had never kept talented people out of my Cabinets just because they were not of my way of thinking, and I was not going to start now' (Thatcher 1993, p. 835).

What emerges from the archives is the different emphasis placed upon the reshuffles during this term. The post-General Election reshuffle (June 1987) was identified by the press as being significant in terms of bringing in 'new talent' (much of it below Cabinet) which gave the government 'new dynamism', with those advancing being defined as the 'young communicators' (Thatcher, MSS, CAC, Press Digest for Thatcher-General Election Aftermath, Cabinet Reshuffle, THCR 3/5/69 f42, 16 June 1987). The primary focus of the June 1988 reshuffle was not so much on new entrants - the centrist Newton being the only new face-but was on the decision to split the Department of Health and Security into two departments. Clarke was made Health Secretary, a fact which the press briefing provided to Thatcher in the immediate aftermath of the reshuffle placed a considerable focus upon. The Mirror said she 'must have gritted [her] teeth to appoint Clarke because he is not [a] natural supporter'; the Express described him as 'capable' but 'distinctly dampish' and Thatcher may have been irked by the suggestion of the Mail that Clarke was a 'future Tory leader' (Thatcher, MSS, CAC, Press Digest for Thatcher, THCR 3/5/81 f193, 26 July 1988).

Although Major was not a new entrant to the Cabinet in the reshuffle of July 1989, he was the main press focus on that reshuffle, as he was dramatically promoted from Chief Secretary to the Treasury to the Foreign Office. When she offered the post to Major, he was initially reticent about accepting what was a significant promotion, fearing that 'people will assume I'm there just to carry out your bidding' and as such he asked whether 'others' were 'better qualified', such as Hurd? (Major 1999, p. 112). Hurd would secure the Foreign Office months later, when Major was moved back to the Treasury to replace Lawson as Chancellor. Major would recall that Thatcher was thinking to offer the Foreign Office to Parkinson, but Major argued that Hurd was the 'obvious choice' (Major 1999, pp. 133-135). Succession planning was said to be a factor in the appointment of Major to the Foreign Office back in July 1989-Thatcher rationalised that 'if he was to have a hope of becoming Party leader, it would be better if he had held one of the three great offices of state' (Thatcher 1993, p. 757). 


\section{Ideological disposition and cabinet departures}

Our third research question asks to what extent was there evidence of an ideological bias in terms of the exits from Cabinet? This calculation is more complex than that on appointments as some exits from Cabinet are voluntary and do not qualify as dismissals, although it is conceivable that a Cabinet minister might choose to resign to avert the possibility of being dismissed. There is also the question of the motive for an enforced removal-it may be ideological, but it could also be motivated by a desire for a generational shift as a Prime Minister eases out older Cabinet members and of course Cabinet ministers may be removed on the grounds of incompetence.

Of those who exited the Cabinet in the first term it is clear than perceptions of competence played a part in the resignation of Humphrey Atkins in the aftermath of the Argentinian invasion of the Falklands-Atkins was a Minister of State in the Foreign Office (but Cabinet ranked as the lead Commons spokesperson on Foreign affairs) and stepped down along with the Foreign Secretary, Lord Carrington. The departure of Angus Maude in January 1981 was due to age (he was approaching seventy years old) and by mutual agreement (Thatcher 1993, p. 29). Of those exiting in the January and September 1981 reshuffles that ideology was a driver is not disputed. In advance of her January 1981 reshuffle Clive Whitmore, who was Thatcher's principal private secretary between 1979 and 1982, recommended the removal from Cabinet of the non-Thatcherite St John Stevas, whom Campbell argued was the most 'expendable' and the 'softest target amongst the wets' (Thatcher MSS, CAC, Whitmore minute to MT ("Version 2"), THCR 1/3/6 f179, 2 January 1981; Campbell 2003, p. 225).

In the lead up to the September 1981 reshuffle Thatcher received advice from Derek Howe, (her political secretary) based on the feedback from a group known as 'fox and goose', who were group of trusted Conservative backbenchers whom Howe sounded out for their insights. It is interesting to note what findings were acted upon and what findings were not acted upon in the subsequent reshuffle. The suggestion that Gilmour 'would not be missed' was shared by Thatcher and acted upon; as was the suggestion that it was 'imperative' that Joseph was moved onto a new ministry, whereupon he was drafted into Education after leaving Industry. However, despite the failings of the loyalist Howell at Energy (who had 'failed to communicate our policy or explain it to the public' which explained why there was 'widespread criticism') he avoided the sack, and moved sideways to Transport (he was sacked two years later, however). Thatcher also rejected the advice to remove Whitelaw from the Home Office, despite 'criticism' of his performance, which was said to be 'not confined to one section of the parliamentary party' (Thatcher MSS, CAC, Whitmore minute to MT ("Version 2"), THCR 1/3/6 f179, 2 January 1981).

The reshuffle of September 1981 was clearly critical and represents the moment in which Thatcher sought to gain greater control over Cabinet by altering its ideological makeup and limiting the ideological opposition to her. It would generate a considerable amount of press praise and criticism. In the aftermath of the controversial September 1981 reshuffle Thatcher was provided with a summary of the press coverage. The left-ward leaning print media were scathing in their criticism with the 
Guardian coverage summarised as follows: Thatcher 'fails utterly at first test at good management' and in doing so she has 'not enhanced' her position and has 'accelerated' the moment when the Conservatives 'will feel there must be an alternative', which contrasted sharply with the Express - 'Maggie dries out wets'; the Sun'Maggie's Monday Massacre'; and the Daily Star - 'purge of wets'; (Thatcher MSS, CAC, 'Press Summary for the PM', THCR, 3/5/9 f36, 15 September 1981).

On the reshuffles of 1981 Lawson argued that Thatcher had reached the following calculations about the leading wets within her first Cabinet: first, there were wets whom 'she feared might cause trouble on the backbenchers', which Lawson argued was her opinion of Walker and Heseltine; and second, there was those who were 'politically incapable of causing trouble on the backbenchers' which was her view of Carlisle and Gilmour (Lawson 1992, pp. 121-122).

Of those who exited the Cabinet in the second term, ideology was seen to be significant in the two most high profiles dismissals from Cabinet. The post-1983 General Election reshuffle saw Pym removed as Foreign Secretary, and she followed this with the dismissal of Prior in the September 1984 reshuffle. It was through her treatment of Pym and Prior, on the back of the dismissals of the St John Stevas, Carlisle and Gilmour back in 1981, that the purge of the 'wets' argument would develope.g., Smith would describe how Thatcher was now exploiting her 'massive majority' to 'remove her remaining critics from the Cabinet' via a process of 'selective sackings' (Smith 1994, pp. 351-352). These assumptions gain even greater credence when placed within the context of the resignation from the Cabinet of Heseltine in January 1986 in the aftermath of the Westland crisis.

Some of the less high-profile departures lacked ideological significance. In her memoirs Thatcher admits she dismissed Rees as Chief Secretary to the Treasury (in the September 1985 reshuffle) as Lawson was 'irritated' (Thatcher 1993, p. 419) by him, and the archives identify how as early as September 1984 how in the 'next reshuffle' removing Rees would be necessary as it was 'now virtually a commitment to Lawson' (Thatcher MSS, CAC, Robin Butler minute for Thatcher, THCR 1/14/14 f103, 11 September 1984). By May 1985 the archives show that no debate was required as Rees was now just listed, without explanation as to why, under the label 'out' (Thatcher, MSS, CAC, Robin Butler minute for Thatcher, THCR, 1/14/14 f96, 23 May 1985). Although Tebbit lobbied for Thatcher to appoint an ideological bedfellow in Lamont in place of Rees, whom Tebbit also just labelled 'out', Thatcher rejected this guidance and selected the ideologically centrist, McGregor, to replace the ideologically centrist, Rees, as number two to Lawson. (Thatcher, MSS, CAC, Tebbit letter to Thatcher, THCR, 1/14/14 f 123, 27 August 1985). The other names repeatedly identified as needing to be removed from the Cabinet in the lead up to the September 1985 reshuffle was the ideologically centrist, Jenkin. Having served as Secretary of State for Social Services (1979-1981); Industry (1981-1983) and then Environment (since 1983) he was widely seen as dispensable by key advisors to Thatcher, possibly on account of the fact that he was approaching sixty. In May 1985 Robin Butler, Principal Private Secretary and later Cabinet Secretary, listed Jenkin as 'out' during a 'preliminary discussion' on the next Cabinet reshuffle, and this sentiment was similarly expressed by Wolfson and Tebbit, from the vantage point as Party Chair, who likewise listed Jenkin as suitable for dismissal. Thatcher, MSS, 
CAC, Robin Butler minute for Thatcher, THCR, 1/14/14 f96, 23 May 1985; 'Wolfson notes: Ministerial Changes', THCR 1/14/14 f129, 22 August 1985; and Tebbit letter to Thatcher, THCR, 1/14/14 f 123, 27 August 1985).

But the departures of Rees and Jenkin were not ideologically loaded. The reshuffle that Thatcher delivered in September 1985 could have been more significant had Thatcher acted upon the advice provided to her. Two names were cited as warranting dismissal from Cabinet, but both of them-Jopling (Minister for Agriculture) and King (Employment Secretary) would survive (Jopling until 1987 and King would last into the Major era, serving as Northern Ireland Secretary 1985-1989 and Defence Secretary 1989-1992) (Thatcher MSS, CAC, Robin Butler minute for Thatcher, THCR 1/14/14 f103, 11 September 1984; Robin Butler minute for Thatcher, THCR, 1/14/14 f96, 23 May 1985; and Tebbit letter to Thatcher, THCR, 1/14/14 f 123, 27 August 1985).

How can we explain the survival of both Jopling and King? The explanation might lie in the advice of Sherbourne (Thatcher's Political Secretary), who informed Thatcher that some of the 'old faces' should go and then listed themJenkin, Rees, Joseph, King and Jopling-before making a reference to the 'night of the long knives' when Prime Minister Harold Macmillan engaged in his famously criticised 1962 reshuffle (Thatcher, MSS, CAC, Sherbourne minutes on reshuffle, THCR, 1/14/14 f136, 22 August 1985; on the 'night of the long knives'). Given the infamy of the latter in terms of mismanaged Cabinet reshuffles (Alderman 1992) this might explain the caution that Thatcher demonstrated in the September 1985 reshuffle, when, although five ministers were considered for dismissal only three exited. It is interesting, nonetheless to note that of the five recommended for dismissal, four were centrists and one was a Thatcherite, but none of them were amongst her critics.

That reshuffle was also significant for the demotion of Brittan from the Home Office. Thatcher came to feel that he was 'not getting the message across on television' (Aitken 2013, p. 514) and as a consequence she switched him across to Trade and Industry. Her choice as his replacement would again reflect her willingness to look beyond her ideological allies, as she turned to Hurd, in what he stated in her memoirs was 'a successful appointment', whom she selected because he was 'immensely reassuring to the police' and because he 'inspired a good deal of confidence in the parliamentary party' (Thatcher 1993, p. 419).

Thatcher was forced into further Cabinet changes in January 1986 as the Westland affair led to the resignations of Heseltine as Defence Secretary and Brittan as Trade and Industry, but her reaction to the loss of a non-Thatcherite critic, in Heseltine and an ideological sympathiser, in Brittan, was not ideologically significant. The centrist, Channon, was brought in to replace Brittan, and fellow centrist, Rifkind, entered the Cabinet as Scottish Secretary, to replace Younger, who was moved across to replace Heseltine at Defence. She did, however, balance out the departure from Cabinet of Joseph, an ideological ally, in May 1986, with a like for like replacement in the shape of Moore. However, all three of these departures from Cabinet in 1986 were not conventional dismissals-Heseltine voluntarily resigned; Brittan was forced into a resignation due to criticism of his conduct during the Westland affair; and Joseph departed by mutual agreement. 
Between 1987 and 1990 there were a significant number of departures from the Cabinet-some voluntary resignations; some forced resignations and some dismissals. Of the twelve who exited, four of them did so after the General Election of 1987, and of these none of them were critics of Thatcherism; two of them were centrists (Jopling and Edwards) and two of them (Biffen and Tebbit) were Thatcherites. The central reshuffle of 1988 (in July) may not have resulted in the dismissal of Moore, but the splitting up of the Department of Health and Social Security into two separate departments, with him remaining at Social Security, certainly hurt him politically. The press briefing delivered to Thatcher on how the reshuffle was covered was clear on this: The Mirror 'Thatcher put the boot in golden boy Moore'; Today 'Moore publicly humiliated'; The Daily Mail 'Moore's empire is sliced in half'; The Sun 'don't cry for John Moore' as 'he failed in vital task of putting right the NHS'; The Independent 'heavy blow' for Moore; and The Times 'a career setback for Moore' who had been 'widely spoken of as a potential leader of the party' (Thatcher, MSS, CAC, Press Digest for Thatcher, THCR 3/5/81 f193, 26 July 1988).

The most planned for reshuffle of the third term-rather than those imposed upon Thatcher by resignations - was the July 1989 reshuffle. The archives reveal that the theme that fed into decision-making was as much presentational-and planning for the next General Election campaign — as it was ideological. For example, Charles Powell, who served as Thatcher's Private Secretary, identified the following for her consideration prior to the reshuffle:

If you intend a major reshuffle before the election, it probably has to be this year to enable the Ministers to master their new jobs as fully as possible. There is a case for quite extensive changes. The feeling is widespread that Labour has youngish and impressive spokesmen in some areas, while some of yours are less impressive. You don't want to go into the election with the risk that people will vote for a change of government when all they want is a change of faces. The time for a reshuffle is probably the end of July. It won't have the same element of surprise as last time. But Ministers seem to prefer to know their fate before the summer holidays. What follows is intended to help you clear your mind. The Big Three: you need to know what you want to do about the big three: Chancellor, Foreign Secretary and Home Secretary. I imagine you will want the Chancellor to go through to the election, always assuming that his personal plans provide for that. Your comments suggest that you may consider moving or even dropping the Foreign Secretary and the Home Secretary. It is only when you reach a decision on these three that a reshuffle can take shape (Thatcher, MSS, CAC, Powell minute for Thatcher, THCR 1/9/18A f13, 19 March 1989).

Thatcher would reject the option of dropping or moving the Home Secretary (Hurd), but she decided to move Howe from the Foreign Office, demoting him to the position of Leader of the House of Commons, but softening the blow by offering him the title of Deputy Prime Minister. By this stage, their ideological alignment over economic strategy had been superseded by their disagreements over European integration, and also by a degree of personal hostility, but such was Howe's standing Thatcher 'dared not risk sacking' him (Shepherd 1991, p. 1). Her treatment of Howe 
and the promotion of Major to the Foreign Office would overshadow the dismissals that generated considerably less press attention. She concluded that she would remove from Cabinet the ideological centrist, Channon, who had served as Trade and Industry Secretary 1986-1987 and then as Transport Secretary since 1987. In her memoirs her explanation as to why he was dismissed was that he was leading a department in which 'public presentation was at a premium' (Thatcher 1993, p. 756) and she replaced him with the more media-savvy, Parkinson. The other dismissal was one which Thatcher admitted was a 'wrench' as she concluded that Moore could no longer continue at the Department for Social Security, as he had failed to recover, 'at least psychologically, from the debilitating illness he suffered' (Thatcher 1993, p. 756).

Thatcher would lose a number of long-standing Cabinet members due to resignation in the period between October 1989 and October 1990. The loss of the ideologically centrist, Fowler, as Employment Secretary in January 1990, was motivated by a desire to 'spend more time with his family' (Walker et al 1990, p. 40). The other three departures were all from the Thatcherite wing of the party. Ridley was forced to resign as Trade and Industry Secretary in July 1990, after he described the proposals for Economic and Monetary Union as a 'German racket designed to take over the whole of Europe' (Lawson 1990).

It was in that environment of policy disagreement and mutual mistrust that would lead to the resignations of both Lawson (in October 1989) and Howe (in October 1990). Lawson resigned in opposition to the influence of her economics advisor, Alan Walters. Prior to his resignation he had issued Thatcher with an ultimatumshe either dismissed Walters or he would resign-which Thatcher noted down as 'an absurd, indeed reprehensible proposition'. (Thatcher, MSS, CAC, MT memoir ('Nigel Lawson's Resignation', Oct 1989, THCR 1/20/7 f4, 26 October 1989). The resignation of Howe symbolised the failings of her style of Prime Ministerial leadership, and combined with their declining position within the opinions throughout 1990, and the proximity of the next General Election inside eighteen months, led to the challenge (by Heseltine) to her leadership of the Conservative Party and her eventual resignation in November 1990. King and Allen argue that her alienation of Lawson and Howe, and her earlier mistreatment of Heseltine, all of whom were politicians of substance — or what they call 'big beasts' - represented her real 'miscalculation' and this was what 'cost her' the premiership (King and Allen 2010, p. 275).

\section{Analysis and conclusions}

This aim of this paper was to use the Norton taxonomy as the basis for a numerical analysis of the ideological balances within the Thatcher Cabinets of 1979 and 1990-i.e., the strength of opinion within the Thatcherite and non-Thatcherite factions within the Cabinet and how these evolved over the course of her time in office. The rationale for doing so was that this provided a basis upon which to validate or challenge the prevailing assumptions of the existing academic literature that we identified in the introduction. To do this we constructed three research questions that 
we wanted to test-a). how ideologically balanced were her respective Cabinets; $b$ ). was there evidence of a bias towards Thatcherites with regard to promotions into Cabinet; and c). was their evidence of a bias towards non-Thatcherites in terms of departures from Cabinet?

Before we proceed to summarise our main findings in relation to these research questions, it is worth addressing one potential criticism of our numeric focus. It could be argued that our approach is problematic as it works on the assumption that all posts are of equal value. That is clearly not the case as certain portfolios are deemed to be a greater political significance. To counter this accusation, it is worth considering the Thatcher Cabinets within the context of a). the political prestige associated with the three 'great offices of state' - the Treasury, Foreign Office and the Home Office; and b). the political significance of where the non-Thatcherite wets were placed within the hierarchy of portfolios more generally. These debates will help us to assess the assess the validity of the accusation that Thatcher tended towards appointing Thatcherites into the key economic portfolios (Evans 2009, p. 102) and in doing so she 'isolated' those critics on the non-Thatcherite right who did remain in Cabinet (Smith 1994, p. 351).

Between 1979 and 1990 Thatcher worked with three Chancellors, two of which, Howe (1979-1983) and Lawson (1983-1989) would be defined as Thatcherite economic liberals; and one (Major 1989-1990) who would be defined as ideologically centrist. Her first Foreign Secretary, Lord Carrington (1979-1982) was a member of the House of Lords, and therefore beyond the parameters of this study, although he generally perceived to be a Heathite. Of the following four that she appointed two were identifiable as critics of Thatcherism-i.e., Pym (1982-1983) and Hurd (1989-); one was an ideological bedfellow, Howe (1983-1989), in economic terms but was increasingly distant from her on questions relating to European integration; and Major (July to October 1989) was ideologically centrist. She entered office with the Heathite, Whitelaw, as her first Home Secretary (1979-1983); before replacing him with an ideological sympathiser in the shape of Brittan between 1983-1985. Brittan was replaced by the non-Thatcherite Hurd in 1985 and when he moved to the Foreign Office in 1989, the ideologically centrist Waddington was drafted into the Home Office. Excluding Carrington, of the eight occupants of the great offices of state, three were Thatcherites dries-Howe, Lawson and Brittan-and three were non-Thatcherite wets-Whitelaw, Pym and Hurd - which hardly amounts to an ideological misuse of patronage. However, it should be noted that between 1983 and 1985 all three offices of state were occupied by Thatcherites-Lawson at the Treasury; Howe at the Foreign Office and Brittan at the Home Office (Lawson 1992, p. 225-226).

Can we detect any biases in terms of the types of departments vis-à-vis ideological disposition?

If we focus on offices identifiable as core to the Thatcherite economic strategy-i.e., the Treasury (both Chancellor and Chief Secretary) Trade and Industry and Employment - then the following emerges. Of those ministers in the House of Commons, a total of eighteen Conservatives occupied these four posts across the Thatcher era. Of them, one was a Thatcherite critic (Prior at Employment in the first two years); seven were identified as ideologically centrist or loyalist (Jenkin, Fowler, 
King, Parkinson, Rees, McGregor and Major) and ten were Thatcherites (Howe, Nott, Joseph, Biffen, Tebbit, Lawson, Ridley, Brittan, Lamont and Lilley). So, the suggestion that Thatcher included critics within her Cabinet but isolated them from portfolios core to her objectives does carry validity. However, this claim has to be placed along the Thatcherite neo-liberal objective of controlling public expenditure and here her appointments to the largest spending departments within governmenti.e., Education and Health and Social Security-are also worth assessing. Across her Prime Ministerial tenure Thatcher appointed ten Conservatives to these portfolios. Of these two were ideologically likeminded (Joseph and Moore); four were ideologically centrist loyalists (Jenkin; Fowler; McGregor and Newton) and four were identifiable as wets: i.e., Carlisle; Baker; Clarke; Waldegrave. These findings could suggest a clear link in terms of portfolio type and the ideological disposition of those appointed, meaning that there could be some legitimacy to the ideas of marginalisation, but it does lead to an additional question: why did Thatcher allocate big spending departments to ministers identifiable with the more interventionist wing of her own party?

On the three central questions which drove this research we can offer the following conclusions. First, when it comes to ideological balance within her Cabinet, the Norton taxonomy helps us to provide more concrete evidence than has previously been available before. From this the balance titled in favour of the non-Thatcherites between May 1979 and September 1981. The contentious reshuffle of September 1981 established a Thatcherite majority within the Cabinet and that majority would be sustained until the July 1989 reshuffle which created a balanced Cabinet. The mini-reshuffle of October 1989 would lead to the non-Thatcherites outnumbering the Thatcherites and this would be sustained for the remainder of her time in office. Her final Cabinet had the lowest level of ideological sympathisers of all of her Cabinets $(n=3)$ and, although the number of ideological centrists $(n=11)$ was higher at the end of her tenure than at any other time, it is also the case that the gap between non-Thatcherites and Thatcherites was larger than at any other time (there were six non-Thatcherites and only three Thatcherites).

Second, when it comes to the issue of promotions into Cabinet, we can identify the following in terms of trends. Excluding herself there were 46 Conservatives appointed to the Cabinet from the House of Commons (all male) and overall, 14 were non-Thatcherites; 20 were loyalists and 12 were Thatcherites. After her initial Cabinet of May 1979 was made up of 8 non-Thatcherites; 5 loyalists and 5 Thatcherites (plus herself), Thatcher subsequently promoted into Cabinet a further 28 new members, of which 6 were non-Thatcherites; 15 were loyalists and 7 were Thatcherites.

Third, when it comes to those departing the Cabinet, we can identify the following in terms of trends. Excluding herself, of the 46 Conservatives who served in her Cabinets, and then also excluding the 19 who were members of her last Cabinet, then we can identify how 27 Conservatives joined and then left her Cabinets. Of those who departed again the ideological profile is reasonably balanced: if we exclude Parkinson, who departed in 1983 and then re-joined in 1987, 8 were nonThatcherites; 9 were loyalists and 9 were Thatcherites. On the question of the form of departure it is clear that five of the non-Thatcherites were clearly dismissed: St 
John Stevans; Gilmour; Carlisle; Pym and Prior (but no wets were dismissed after 1984), whereas only two of the Thatcherite departures were clearly dismissals: Biffen and Moore, in 1987 and 1989 respectively. In terms of policy-based resignations Thatcher lost more Cabinet members from her own ideological subgroupLawson and Howe - as she did from her critics-Heseltine.

Overall, the Norton taxonomy helps us to challenge the assumptions within the existing academic literature about how Thatcher used her powers of patronage in a way that was biased in favour of Thatcherites and against non-Thatcherites. The archives demonstrate to us that the ideological disposition of Cabinet members was clearly a calculation for those advising Thatcher. Her subsequent decision-making does demonstrate her desire to shift the balance to the right in September 1981, but the archives also enable us to understand the caution that existed in terms of the ideological balance of the Cabinet, with the reshuffle of September 1985 being a notable example of her desire that her Cabinet was seen to be more ideologically balanced. This was achieved by the advancement of a 'new generation' of Conservatives, whom whilst not 'instinctive Thatcher supporters', were 'happy to serve' (Campbell 2003, p. 225). The ideological significance of the September 1981 reshuffle is not disputed within this study, but by using the Norton taxonomy as a guide, and by exploiting the archival material on subsequent reshuffles it is clear that, thereafter, presentational skill (i.e., competence) mattered as much as ideology. This study, in effect, sought to test a claim that Thatcher made in her memoirs - that 'the Cabinet to some extent reflect the varying views in the Parliamentary Party' (Thatcher 1993, p. 418), and it has demonstrated that her appointments (if not her portfolio allocation) showed a greater sensitivity to this concern than academics have tended to acknowledge. On why, Thatcher would admit that 'I generally found that the (Tory) left seemed to be best at presentation' (Thatcher 1993, p. 418).

Open Access This article is licensed under a Creative Commons Attribution 4.0 International License, which permits use, sharing, adaptation, distribution and reproduction in any medium or format, as long as you give appropriate credit to the original author(s) and the source, provide a link to the Creative Commons licence, and indicate if changes were made. The images or other third party material in this article are included in the article's Creative Commons licence, unless indicated otherwise in a credit line to the material. If material is not included in the article's Creative Commons licence and your intended use is not permitted by statutory regulation or exceeds the permitted use, you will need to obtain permission directly from the copyright holder. To view a copy of this licence, visit http://creativecommons.org/licen ses/by/4.0/.

\section{References}

Aitken, J. 2013. Margaret Thatcher: Power and Personality. London: Bloomsbury.

Alderman, K. 1992. Harold Macmillan's “"Night of the Long Knives.” Contemporary Record 6 (2): $243-265$.

Evans, S. 2009. The Not So Odd Couple: Margaret Thatcher and One Nation Conservatism. Contemporary British History 23 (1): 101-121.

Fowler, N. 1991. Ministers Decide: A Personal Memoir of the Thatcher Years. London: Chapmans. 
Heppell, T. 2002. The Ideological Composition of the Parliamentary Conservative Party 1992 to 1997. British Journal of Politics and International Relations 4 (2): 299-324.

Heppell, T. 2005. Ideology and Ministerial Allocation in the Major Government 1992-1997. Politics 25 (3): 144-152.

Heppell, T. 2008. Choosing the Tory Leader: Conservative Party Leadership Elections from Heath to Cameron. London: I B Tauris.

Heppell, T. 2020. The Ideological Composition of the Parliamentary Conservative Party from Thatcher to May. In Thatcherism in the $21^{\text {st }}$ Century Century, ed. A. Mullen, S. Farrall, and D. Jeffery. Palgrave: Basingstoke.

Holmes, M. 1989. Thatcherism: Scope and Limits 1983-1987. London: Macmillan.

King, A. 1994. Ministerial Autonomy in Britain. In Cabinet Ministers and Parliamentary Government, ed. M. Laver and K. Shepsle. Cambridge: Cambridge University Press.

King, A., and N. Allen. 2010. "Off with their Heads": British Prime Ministers and the Power to Dismiss. British Journal of Political Science 40 (2): 249-278.

Lawson, D. 1990. 'Saying the Unsayable about the Germans', The Spectator, 14 July.

Lawson, N. 1992. The View from No.11: Memoirs of a Tory Radical. London: Corgi.

Major, J. 1999. John Major: The Autobiography. London: HarperCollins.

Moore, C. 2013. Margaret Thatcher: The Authorised Biography—Volume One: Not for Turning. London: Penguin Books.

Norton, P. 1990. The Lady's not for turning but what about the rest?' Margaret Thatcher and the Conservative Party 1979-89. Parliamentary Affairs 43 (1): 41-58.

Prior, J. 1986. A Balance of Power. London: Hamish Hamilton.

Shepherd, R. 1991. The Power Brokers. The Tory Party and its Leaders. London: Hutchinson.

Smith, M. 1994. The Core Executive and the Resignation of Mrs Thatcher. Public Administration. 72 (3): 341-363.

Tebbit, N. 1989. Upwardly Mobile. London: Futura.

Thatcher, M. 1993. The Downing Street Years. London: Harper Collins.

Thomas, G. 1998. Prime Minister and Cabinet Today. Manchester: Manchester University Press.

Walker, D., A. Adonis, R. Worcester, and P. Catterall. 1990. Record Review, December 1989-January 1990. Contemporary Record 3 (4): 40-44.

Publisher's Note Springer Nature remains neutral with regard to jurisdictional claims in published maps and institutional affiliations. 